\title{
Religiusitas dan Ketidakjujuran Akademik pada Mahasiswa Kristen di Universitas Kristen di Tangerang
}

\author{
Anita Djie ${ }^{1}$ \& Jessica Ariela ${ }^{1 a}$ \\ ${ }^{1}$ Universitas Pelita Harapan, Tangerang, Indonesia \\ ajessica.ariela@uph.edu
}

\section{Religiosity and Academic Dishonesty Among Christian College Students in a Christian University in Tangerang}

\begin{abstract}
Academic dishonesty is a frequent problem in university and negatively impacts college students' future. Therefore, this problem is necessary to be highlighted and solved. Prior studies had shown the importance of religiosity in the lives of college students. Students with high religiosity can remember and use their religious values to comprehend every university-related decision. By having high religiosity. Students can potentially apply their religious values as lifestyle and can have religious communities that can remind the students not to attempt things prohibited by their religion. Therefore, high religiosity should have been helpful to promote academic honesty. This study aimed to investigate whether there is a correlation between religiosity and academic dishonesty in 152 Christian students in a Christian university in Tangerang. This research was conducted using a quantitative method with The Four Basic Dimensions of Religiousness and Academic Dishonesty Scale as instruments of research. The result of the study showed that there was a significant negative correlation between religiosity and academic dishonesty $(r s=-.200, p<.05)$. This finding showed that the higher the religiosity, the lower the academic dishonesty. Related additional analysis was also discussed.
\end{abstract}

Manuscript type: Original Research

Article history:

Received: 25 October 2020

Accepted: 26 January 2021

Available online: 28 January 2021

Keywords:

Religiosity

Academic Dishonesty

College Student

Christianity

\begin{abstract}
Abstrak
Ketidakjujuran akademik merupakan masalah yang sering terjadi di perguruan tinggi dan menimbulkan dampak-dampak negatif pada masa depan mahasiswa. Oleh karena itu, masalah ini penting untuk diperhatikan dan diselesaikan. Penelitian sebelumnya menunjukkan pentingnya religiusitas dalam hidup mahasiswa. Religiusitas yang tinggi dapat membantu mahasiswa untuk bisa menggunakan nilai-nilai agama dalam setiap keputusan yang berhubungan dengan perkuliahannya. Memiliki religiusitas yang tinggi juga berpotensi membuat mahasiswa mampu menerapkan nilai-nilai keagamaannya sebagai gaya hidup dan membantunya memiliki komunitas-komunitas keagamaan sebagai pengingat untuk tidak melakukan hal-hal yang tidak diperkenan agama. Dengan demikian, religiusitas yang tinggi pada mahasiswa seharusnya dapat membantu mahasiswa untuk dapat jujur secara akademik. Penelitian ini bertujuan untuk menelusuri apakah terdapat korelasi antara religiusitas dan ketidakjujuran akademik pada 152 mahasiswa yang beragama Kristen di sebuah Universitas Kristen di Tangerang. Penelitian dilakukan menggunakan metode kuantitatif dengan alat ukur The Four Basic Dimensions of Religiousness dan Academic Dishonesty Scale. Hasil penelitian menujukkan bahwa terdapat hubungan negatif yang signifikan antara religiusitas dan ketidakjujuran akademik ( $r s=-.200, p<.05)$. Hasil ini memperlihatkan bahwa semakin tinggi religiusitas, maka semakin rendah ketidakjujuran akademik.
\end{abstract}

Kata Kunci: Religiusitas; Ketidakjujuran Akademik; Mahasiswa; Kristen 


\section{PENDAHULUAN}

Ketidakjujuran akademik merupakan masalah serius yang secara umum banyak terjadi di institusi pendidikan serta memiliki dampak yang negatif terhadap masa depan kerja mahasiswa (Saana, Ablordeppey, Mensah, \& Karikari, 2016). Mahasiswa yang melakukan ketidakjujuran akademik memiliki kemungkinan yang lebih besar untuk melanggar peraturan dan melakukan perilaku tidak etis dalam pekerjaannya (Rujoiu \& Rujoiu, 2014; Harding, Carpenter, Finelli, \& Passow, 2004; Lawson, 2004).

Fenomena ketidakjujuran akademik juga terjadi di perguruan-perguruan tinggi Indonesia, seperti plagiarisme (Hakim, 2014; BBC Indonesia, 2017), menyontek, dan penggunaan joki untuk ujian (Mukti, 2017). Padahal sudah ada sanksi-sanksi yang diberikan oleh perguruan-perguruan tinggi menyangkut ketidakjujuran akademik, seperti harus mengulang mata kuliah dan diberhentikan dari perkuliahan.

Ketidakjujuran akademik didefenisikan sebagai perilaku-perilaku yang tidak etis dalam bidang akademik untuk mendapatkan suatu keuntungan, seperti menyontek, plagiarism, penyalahgunaan teknologi, dan meminta bantuan dari pihak lain. Ketidakjujuran akademik menjadi empat dimensi, yaitu cheating atau perilaku tidak etis saat ujian, plagiarism atau perilaku tidak etis saat pengerjaan tugas, electronic cheating atau menyontek menggunakan teknologi, dan seeking for outside help atau menggunakan bantuan dari pihak lain (Iyer \& Eastman, 2008).

Berdasarkan survei awal yang dilakukan oleh peneliti secara online kepada 82 orang mahasiswa di suatu perguruan tinggi swasta, terdapat sebanyak 14,6 \% mahasiswa yang pernah menggunakan hasil karya orang lain untuk tugas tanpa menyertakan referensi dan sitasi secara sengaja, 86,6\% mahasiswa pernah memberikan jawaban tugas kepada temannya, 80,5\% mahasiswa pernah menerima jawaban tugas dari temannya, 68,3\% mahasiswa pernah memberikan jawaban kepada temannya saat ujian, 63,4\% mahasiswa pernah menerima jawaban dari temannya saat ujian. Tidak hanya itu, sebanyak 18,3\% mahasiswa pernah meminta temannya atau orang lain untuk membuatkan tugasnya, 46,3\% mahasiswa pernah membuatkan tugas untuk temannya atau orang lain, $35,4 \%$ mahasiswa pernah menggunakan handphone atau gawai lainnya untuk mencari jawaban di internet saat ujian, 25,6\% mahasiswa pernah memberikan jawaban kepada teman atau orang lain saat ujian menggunakan handphone atau gawai lainnya, dan 29,3\% mahasiswa pernah menggunakan handphone atau gawai lainnya untuk mendapatkan jawaban dari teman atau orang lain saat ujian. Melalui hasil survei ini, dapat dilihat bahwa fenomena ketidakjujuran akademik masih merupakan sesuatu yang sering dilakukan mahasiswa.

Mahasiswa adalah individu yang berada dalam tahapan emerging adulthood yang lebih kritis dalam meninjau dan menentukan nilai-nilai serta kepercayaannya (Arnett, 2004; Arnett, 2016). Pada tahapan ini mahasiswa menganggap agama sebagai sesuatu yang penting bagi identitas dirinya dan oleh karenanya, nilai-nilai agama yang dianut dapat memengaruhi dan terefleksikan melalui keputusan yang diambilnya (Arnett, 2004), salah satunya adalah keputusan untuk melakukan ketidakjujuran akademik. Religiusitas didefinisikan oleh Saroglou $(2011 ; 2014)$ sebagai ketertarikan dan keterlibatan individu dengan agama, dan yang terbagi menjadi empat dimensi, yaitu believing, bonding, behaving, dan belonging. Dimensi believing meliputi kepercayaan individu mengenai adanya sesuatu yang transenden atau yang melebih individu dan dapat memberikan suatu makna hidup, dimensi bonding mencakup emosi dan pengalaman individu terhadap yang transenden dan termanifestasi secara privat (berupa doa dan meditasi) maupun secara publik (menghadiri upacara keagamaan, dan sebagainya), dimensi behaving menekankan bagaimana individu dapat menentukan apa yang benar dan apa yang salah berdasarkan nilai-nilai moral dari agama atau kepercayaannya, dan dimensi belonging adalah keterikatan dengan suatu kelompok atau komunitas yang dapat membentuk identitas sosial individu (Saroglou, 2011). 
Melalui penjabaran Saroglou, dapat disimpulkan bahwa individu yang religius adalah individu yang memiliki suatu kepercayaan terhadap sesuatu yang transenden yang memberikan makna hidup, melakukan suatu aktivitas yang dapat menghubungkan individu secara emosional dengan apa yang dipercayai oleh individu, mengetahui dan dapat membedakan pemikiran serta perilaku yang benar dan salah, serta memiliki keterikatan dan menjadi bagian dari suatu kelompok atau komunitas dengan kepercayaan yang serupa.

Penelitian ini dilakukan pada mahasiswa Kristen yang berkuliah di sebuah perguruan tinggi swasta yang berlandaskan iman agama Kristiani. Umat Kristiani percaya kepada Allah Tritunggal yang menciptakan langit, bumi dan isinya (Tong, 2012), dan melihat Tuhan sebagai sosok yang maha adil dan juga maha pengasih (Zacharias dan Geisler, 2003), serta maha hadir atau omnipresence (Kirkpatrick, 2005; Arnold \& Arnold, 2015). Kepercayaan ini dapat membuat individu berperilaku secara bermoral. Hal ini dikarenakan individu sadar bahwa Tuhan yang maha melihat dapat memberikan hukuman ataupun upah kepada individu (Pyysiainen, 2017). Namun, individu Kristen juga sadar akan makna hidupnya serta kasih dan pengorbanan Allah kepadanya dan meresponi makna hidup dan kasih tersebut dengan melakukan perintahNya (Arnold \& Arnold, 2015). Di samping itu, individu Kristen percaya bahwa manusia telah jatuh ke dalam dosa tetapi Tuhan telah mengorbankan putraNya untuk menebus dosa manusia yang membuat umat Krsitiani sadar dan meresponi kasihNya dengan tidak melakukan dosa (Arnold \& Arnold, 2015). Umat Kristiani meyakini bahwa dirinya diciptakan untuk memuliakan nama Tuhan (Arnold \& Arnold, 2015), dengan cara menyerahkan diri sepenuhnya kepada-Nya, mengasihi Tuhan, dan mengikuti perintah-Nya (Arnold \& Arnold, 2015; Prasad, 2013). Dalam konteks keyakinan seperti inilah mahasiswa Kristen memahami makna hidupnya dan meresponi kasih Allah dengan tidak melakukan ketidakjujuran akademik.

Di samping itu, rasa takut akan penghukuman dapat membuat seseorang cenderung melakukan perilaku yang jujur (Shariff \& Norenzayan, 2011). Oleh karenanya, saat mahasiswa Kristen melakukan hal-hal yang tidak menyenangkan hati Tuhan, dirinya akan merasa tidak tenang. Emosi tersebut dapat membuatnya memutuskan untuk tidak melakukan ketidakjujuran akademik. Selain perasaann tersebut, Alkitab yang merupakan penuntun umat Kristiani telah memberikan panduan mengenai apa yang benar dan apa yang salah. Ini dapat menjadi cara mahasiswa untuk menyelesaikan permasalahan moralnya. Dalam hal ini, mahasiswa sadar bahwa ketidakjujuran akademik adalah sesuatu yang salah secara moral Kristiani dan akhirnya memustuskan tidak melakukan ketidakjujuran akademik.

Tidak hanya melalui Alkitab, komunitas-komunitas Kristen yang diikuti mahasiswa dapat menjadi identitas sosial mahasiswa (Saroglou, 2011) serta menjadi pengingat dan sarana diskusi mengenai nilai-nilai Kristiani yang dianut (Arnold \& Arnold, 2015). Komunitas dan Alkitab yang dipercayai oleh mahasiswa dapat meningkatkan kontrol diri mahasiswa (DeWall, Carter, McCullough, Fincham, Pond, Lambert, \& Nezlek, 2014), sehingga mahasiswa dapat memilih untuk tidak melakukan ketidakjujuran akademik.

Melalui keterkaitan antar dimensi religositas menurut Saraglou, maka secara teoretis dapat disimpulkan bahwa mahasiswa Kristen yang memiliki religiusitas yang baik akan cenderung untuk tidak melakukan ketidakjujuran akademik, karena mahasiswa Kristen dengan religiusitas yang baik akan cenderung mengerti dan memahami tujuan serta pentingnya nilai-nilai agama yang dianut tidak hanya dari segi ketaatan dalam berperilaku (behaving) maupun kognitif (believing), tetapi juga dari segi afektif (bonding) yang pada akhirnya dapat membuat mahasiswa Kristen menjadikan agama Kristen dan komunitasnya sebagai bagian dari identitas sosialnya (belonging). Dengan demikian, mahasiswa Kristen yang religius cenderung mengaplikasikan nilai-nilai moral keagamaannya dalam 
setiap keputusan yang akan diambil, yaitu salah satunya adalah keputusan untuk tidak melakukan ketidakjujuran akademik.

Namun di sisi lain, menurut penelitian yang dilakukan oleh Ismail dan Omar (2017) dinyatakan bahwa idealisme serta kepercayaan terhadap agama (religious belief) berhubungan secara negatif dengan ketidakjujuran akademik dan individu yang memiliki kepercayaan yang tinggi terhadap agamanya lebih cenderung menggunakan prinsip-prinsip agamanya dalam membuat keputusan. Dengan demikian, terdapat dua sisi mengenai keterkaitan antara religiusitas dan ketidakjujuran akademik. Pertama, terdapat penelitian-penelitian yang mendukung adanya korelasi negatif yang signifikan antara religiusitas dan ketidakjujuran akademik (Burton, Talpade, \& Haynes, 2011; Hongwei, Glanzer, Johnson, Sriram, \& Moore, 2016; Nelson, James, Miles, Morrell, \& Sledge, 2016). Namun, pada sisi yang berlainan, terdapat penelitian yang memperlihatkan bahwa religiusitas dan ketidakjujuran akademik tidak berkaitan (Huelsman, Piroch, \& Wasieleski, 2007; Shariff \& Norenzayan, 2011; Hadjar, 2017). Adanya perbedaan dari hasil-hasil penelitian sebelumnya membuat kajian terhadap hubungan antara religiusitas dan ketidakjujuran akademik penting dan menarik untuk diteliti.

\section{METODE}

\section{Partisipan}

Penelitian ini melibatkan 152 partisipan yang merupakan mahasiswa S1 aktif di sebuah Universitas Kristen di Tangerang, berusia 18-25 tahun,dan telah mengikuti mata kuliah Pendidikan Agama Kristen. Teknik pengambilan data dilakukan dengan cara purposive sampling yang mengambil sampel dengan pertimbangan atau karakteristik tertentu yang sesuai dengan tujuan penelitian (Sugiyono, 2014).

\section{Desain Penelitian}

Penelitian bersifat kuantitatif non eksperimental dan menggunakan metode korelasional atau yang hanya melihat hubungan antara dua variabel tanpa menjelaskan hubungan sebab-akibat dari kedua variabel (Gravetter \& Forzano, 2012). Penelitian ini juga bersifat cross-sectional.

\section{Prosedur}

Peneliti membuat survei secara daring menggunakan Google Form untuk melihat relevansi dari fenomena yang ada di universitas tersebut Alat ukur yang digunakan oleh peneliti adalah Academic Dishonesty Scale (Iyer \& Eastman, 2008) untuk mengukur ketidakjujuran akademik, dan alat ukur The Four Basic Dimensions of Religiousness Scale (Saroglou, 2011) untuk mengukur religiusitas. Kedua alat tes ini diterjemahkan ke Bahasa Indonesia oleh peneliti. Peneliti melakukan uji coba terlebih dahulu untuk mengukur validitas dan reliabilitas alat ukur yang sudah diterjemahkan ke bahasa Indonesia. Uji coba dilakukan secara online melalui Google Form serta disebarkan secara personal approach dengan media sosial Line. Uji coba dilakukan kepada 31 orang mahasiswa yang memenuhi kriteria yang sama dengan kriteria sampel penelitian. Setelah membuang beberapa butir alat ukur sebanyak dua kali pada alat ukur Academic Dishonesty Scale, alat ukur akhirnya telah memiliki nilai reliabilitas dan validitas yang sesuai dengan nilai standar penerimaan reliabilitas 
internal, yaitu di atas .500 (Goforth, 2015) dan di atas .200 untuk inter-item correlation (Piedmont, 2014). Hasil rangkuman uji coba dapat dilihat pada tabel $1 .$.

Tabel 1

Tabel Rangkuman Hasil Validitas dan Reliabilitas Data Uji coba

\begin{tabular}{lcc}
\hline \multicolumn{1}{c}{ Konstruk } & Validitas & Reliabilitas \\
\hline Ketidakjujuran Akademik & $\mathbf{. 3 4 5}-.845$ & $\mathbf{. 8 7 9}$ \\
Cheating & $.627-.719$ & .856 \\
Seeking Outside Help & $.423-.667$ & .721 \\
Plagiarism & $.412-.656$ & .735 \\
Electronic Cheating & .501 & .668 \\
Religiusitas & $\mathbf{. 5 8 3 - . 8 2 5}$ &. $\mathbf{9 3 8}$ \\
Believing & $.671-.778$ & .814 \\
Bonding & $.650-.868$ & .883 \\
Behaving & $.578-.787$ & .839 \\
Belonging & $.611-.829$ & .848 \\
\hline
\end{tabular}

Setelah memastikan alat ukur sudah valid dan reliabel, barulah peneliti menyebarkan kuesioner untuk penelitian secara online melalui Google Form dan menyebarkan kuesioner hardcopy di sekitar kawasan universitas. Kuesioner online disebar melalui media sosial. Setelahnya peneliti melakukan uji validitas dan reliabilitas alat ukur dari data yang diperoleh dari subyek penelitian. Tabel 2. adalah rangkuman hasil validitas dan reliabilitas alat ukur.

\section{Teknik Analisis}

Peneliti menggunakan corrected item-total correlation untuk uji validitas dan Cronbach's alpha untuk uji reliabilitas. Sementara itu, teknik Kolmogorov-Smirnov digunakan untuk uji normalitas. Peneliti mendapati data penelitian yang dimiliki tidak normal. Data penelitian yang tidak normal membuat peneliti melakukan uji korelasi menggunakan Spearman's Rho. Sementara untuk uji beda, peneliti menggunakan teknik Mann-Whitney U dan Kruskal-Wallis H.

Tabel 2.

Tabel Rangkuman Hasil Validitas dan Reliabilitas Alat Ukur

\begin{tabular}{lcc}
\hline \multicolumn{1}{c}{ Konstruk } & Validitas & Reliabilitas \\
\hline Ketidakjujuran Akademik & $\mathbf{. 2 5 3 - . 7 3 7}$ & $\mathbf{. 8 7 1}$ \\
Cheating & $.598-.731$ & .862 \\
Seeking Outside Help & .763 & .865 \\
Plagiarism & $.284-.507$ & .617 \\
Electronic Cheating & .637 & .767 \\
Religiusitas & $\mathbf{. 5 9 2 - . 7 8 3}$ &. $\mathbf{9 3 2}$ \\
Believing & $.695-.765$ & .853 \\
Bonding & $.672-.741$ & .840 \\
Behaving & $.514-.694$ & .778 \\
Belonging & $.633-.778$ & .829 \\
\hline
\end{tabular}




\section{ANALISIS DAN HASIL}

Pada data demografis usia tidak ditemukan adanya korelasi antara usia dan variabel religiusitas ( $p>.05$ ) serta variabel ketidakjujuran akademik ( $p>.05)$. Namun, ketika dianalisis uji beda berdasarkan jenis kelamin $\left(\mathrm{n}_{\text {pria }}=52\right.$, nwanita $\left.=100\right)$, ditemukan bahwa pria lebih memiliki kecenderungan untuk melakukan ketidakjujuran akademik $(\mathrm{U}=1814.5, \mathrm{p}=.002)$ daripada wanita. Secara spesifik, pria lebih cenderung melakukan cheating $(\mathrm{U}=1715.5, \mathrm{p}=.001)$ dan electronic cheating $(\mathrm{U}=1772, \mathrm{p}=.000)$ daripada wanita. Sementara itu, wanita cenderung lebih religious daripada pria ( $U=2066.5, p=.038)$, secara spesifik, skor dimensi believing pada wanita cenderung lebih tinggi dibandingkan pria $(\mathrm{U}=1924, \mathrm{p}=.008)$.

Hasil dari penelitian menunjukkan bahwa terdapat korelasi negatif yang signifikan antara religiusitas dan ketidakjujuran akademik ( $r s=-.200, \mathrm{p}<.05$ ). Peneliti juga melakukan uji korelasi terhadap tiap dimensi dari variabel yang dapat dilihat dari rangkuman tabel uji korelasi di bawah ini.

Tabel 3.

Tabel Hasil Uji Korelasi Antara Variabel dan Dimensi serta Antar Dimensi

\begin{tabular}{|c|c|c|c|c|c|c|}
\hline & & \multicolumn{5}{|c|}{ Ketidakjujuran Akademik } \\
\hline & & Total & Cheating & $\begin{array}{c}\text { Seeking Outside } \\
\text { Help }\end{array}$ & Plagiarism & $\begin{array}{c}\text { Electronic } \\
\text { Cheating }\end{array}$ \\
\hline \multirow{5}{*}{ 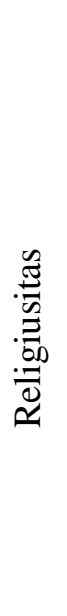 } & Total & $\begin{array}{c}-.200^{*} \\
(p=.014)\end{array}$ & $\begin{array}{c}-.125 \\
(p=.126)\end{array}$ & $\begin{array}{c}-.167^{*} \\
(p=.039)\end{array}$ & $\begin{array}{c}-.194^{*} \\
(p=.017)\end{array}$ & $\begin{array}{c}-.177 * \\
(p=.029)\end{array}$ \\
\hline & Believing & $\begin{array}{l}-.292 * * \\
(p=.000)\end{array}$ & $\begin{array}{l}-.235^{* *} \\
(p=.004)\end{array}$ & $\begin{array}{l}-.263 * * \\
(p=.001)\end{array}$ & $\begin{array}{c}-.195^{*} \\
(p=.016)\end{array}$ & $\begin{array}{c}-.186^{*} \\
(p=.022)\end{array}$ \\
\hline & Bonding & $\begin{array}{c}-.051 \\
(p=.531)\end{array}$ & $\begin{array}{c}.011 \\
(p=.894)\end{array}$ & $\begin{array}{c}-.026 \\
(p=.754)\end{array}$ & $\begin{array}{c}-.129 \\
(p=.114)\end{array}$ & $\begin{array}{c}-.061 \\
(p=.453)\end{array}$ \\
\hline & Behaving & $\begin{array}{c}-.203^{*} \\
(p=.012)\end{array}$ & $\begin{array}{c}-.100 \\
(p=.219)\end{array}$ & $\begin{array}{l}-.212 * * \\
(p=.009)\end{array}$ & $\begin{array}{l}-.225 * * \\
(p=.005)\end{array}$ & $\begin{array}{l}-.226 * * \\
(p=.005)\end{array}$ \\
\hline & Belonging & $\begin{array}{c}-.161^{*} \\
(p=.048)\end{array}$ & $\begin{array}{c}-.124 \\
(p=.129)\end{array}$ & $\begin{array}{c}-.088 \\
(p=.282)\end{array}$ & $\begin{array}{c}-.140 \\
(p=.086)\end{array}$ & $\begin{array}{c}-.194 * \\
(p=.017)\end{array}$ \\
\hline
\end{tabular}

**Korelasi signifikan pada tingkat .01; * Korelasi signifikan pada tingkat .05

\section{DISKUSI}

Hasil penelitian menunjukkan bahwa terdapat korelasi negatif yang signifikan antara religiusitas dengan ketidakjujuran akademik pada mahasiswa Kristen di universitas itu (rs= -.200, $\mathrm{p}<.05$ ). Hal ini menunjukkan bahwa semakin tinggi tingkat religiusitas individu, maka semakin rendah ketidakjujuran akademik individu. Sebaliknya, semakin rendah tingkat religiusitas individu, maka semakin tinggi tingkat ketidakjujuran akademik individu. Hasil penelitian ini sesuai dengan penelitian sebelumnya yang menemukan adanya korelasi negatif yang signifikan antara religiusitas 
dengan ketidakjujuran akademik (Burton, Talpade, \& Haynes, 2011; Hongwei, Glanzer, Johnson, Sriram, \& Moore, 2016; Nelson, James, Miles, Morrell, \& Sledge, 2016).

Korelasi antara religiusitas dan ketidakjujuran akademik dapat dijelaskan melalui pemahaman dan internalisasi individu terhadap kepercayaan agama Kristen. Internalisasi memampukan individu untuk melakukan suatu perilaku berdasarkan kemauannya sendiri (Neyrinck, Vansteenkiste, Lenz, Duriez, dan Hutsebaut, 2006). Dalam hal ini, mahasiswa Kristen menginternalisasi nilai-nilai agama yang diyakini dan pada akhirnya melakukan perilaku yang sesuai dengan kepercayaan Kristen dalam kehidupan perkuliahannya, termasuk tidak melakukan ketidakjujuran akademik. Internalisasi tidak hanya berefek kepada perilaku individu tetapi juga haruslah sejalan dengan tujuan hidup individu (Neyrinck, Vansteenkiste, Lenz, Durienz, \& Hutsebaut, 2006).

Agama Kristen tidak hanya sebuah kepercayaan saja, tetapi agama Kristen memberikan makna hidup kepada umatnya, yaitu untuk memuliakan Allah dan menikmati kebersamaan di dalamNya (Arnold \& Arnold, 2015). Umat Kristiani meyakini bahwa salah satu cara untuk memuliakan Tuhan adalah dengan menaati perintahNya (Arnold \& Arnold, 2015). Oleh karenanya, mahasiswa Kristen menginternalisasi nilai-nilai Kristiani dan memaknainya dengan tidak melakukan ketidakjujuran akademik.

Kepercayaan dan pemaknaan terhadap iman Kristiani ini juga tercermin dari hasil penelitian penelitian yang memperlihatkan bahwa dimensi believing memiliki korelasi negatif yang signifikan paling besar dengan ketidakjujuran akademik ( $r s=-.292, p<.01$ ) dan berkorelasi negatif secara signifikan dengan semua dimensi ketidakjujuran akademik, yaitu cheating ( $\mathrm{rs}=-.235, \mathrm{p}<.01$ ), seeking outside help ( $\mathrm{rs}=-.263, \mathrm{p}<.01$ ), plagiarism ( $\mathrm{rs}=-.195, \mathrm{p}<.05$ ), serta electronic cheating ( $\mathrm{rs}=-.186$, $\mathrm{p}<.05$ ). Hal ini juga menunjukkan sentralitas dimensi believing pada mahasiswa Kristen yang menjadi landasan pemahaman dan pemaknaan agama dalam bersikap, dalam hal ini adalah dalam melakukan ketidakjujuran akademik.

Individu yang menginternalisasi nilai-nilai agamanya juga cenderung memiliki regulasi diri yang baik (Koole, McCullough, Kuhl, \& Roelofsma, 2010). Kontrol diri erat kaitannya dengan dimensi behaving (Saroglou, 2011). Individu yang telah menginternalisasi nilai-nilai Kristiani memiliki kontrol diri untuk tidak melakukan perilaku yang salah secara moral agamanya. Dalam hal ini, umat Kristiani menggunakan Alkitab sebagai panduan untuk menentukan perilaku yang benar dan yang salah (Wright, 2006). Alkitab tidak hanya sebagai aturan saja, tetapi merupakan gaya hidup umat Kristiani yang memengaruhi kehidupan sehari-harinya, serta berfungsi sebagai suatu aktualisasi akan kepercayaan yang diyakini oleh umat Kristiani (Arnold \& Arnold, 2015). Hal ini dapat menjelaskan mengapa dimensi behaving memiliki korelasi negatif yang signifikan dengan ketidakjujuran akademik ( $\mathrm{rs}=-.203, \mathrm{p}<.05$ ).

Dimensi religiusitas lainnya, yaitu dimensi belonging juga berkorelasi negatif secara signifikan dengan ketidakjujuran akademik ( $\mathrm{rs}=-.161, \mathrm{p}<.05$ ). Korelasi belonging dengan ketidakjujuran akademik dapat dijelaskan melalui komunitas gereja individu yang dapat menjadi sumber identitas sosial dan pengingat individu serta sarana individu untuk berdiskusi mengenai norma-norma agama yang dianut (Saroglou, 2011; Arnold \& Arnold, 2015). Dalam hal ini, mahasiswa Kristen yang senang berkumpul bersama komunitas Kristennya akan mengikuti nilai-nilai dan perilaku yang dilakukan oleh teman-teman di komunitas Kristennya. Tidak hanya itu, komunitas 
Kristen yang diikuti oleh individu dapat menjadi ajang individu untuk berdiskusi mengenai perilakuperilaku yang diterima maupun tidak dapat diterima seturut ajaran agamanya, dan komunitas ini menjadi accountability partner bagi individu. Partisipasi dalam komunitas Kristen yang diikuti oleh mahasiswa dapat menjadi alasan yang membuat dimensi belonging memiliki korelasi yang negatif secara signifikan dengan sikap tidak jujur secara akademik.

Namun, hal yang menarik adalah dimensi belonging hanya berkorelasi negatif secara signifikan dengan electronic cheating ( $\mathrm{rs}=-.194, \mathrm{p}<.05$ ), dan tidak berkorelasi dengan bentuk ketidakjujuran akademik lainnya. Perlu dicatat juga bahwa mahasiswa tidak hanya berkuliah dengan teman-teman dari komunitas agamanya, tetapi juga teman-teman dari luar komunitas agamanya. Dapat dilihat, bentuk-bentuk ketidakjujuran akademik yang tidak berkorelasi dengan belonging kebanyakan adalah yang dilakukan bersama orang lain, seperti cheating maupun seeking outside help. Stogner, Miller, dan Marcum (2012) menemukan dalam penelitiannya bahwa social learning dapat menjelaskan alasan individu melakukan ketidakjujuran akademik. Aker (dalam Stogner, Miller, \& Marcum, 2012) menjelaskan bahwa dalam social learning theory, individu mempelajari suatu nilai dan perilaku melalui interaksi sosialnya. Saat individu melihat orang lain menyontek, persepsi individu terhadap perilaku menyontek salah secara moral dapat menurun dan meningkatkan kemungkinan individu untuk menyontek (O’Rourke, Barnes, Deaton, Fulks, Ryan, \& Rettinger, 2010). Aker (dalam Stogner, Miller, \& Marcum, 2012) sempat menjelaskan bahwa individu dapat mengimitasi perilaku orang lain untuk dapat diikuti. Dengan demikian, jika lingkungan sosial individu melakukan kecurangan ini, individu juga dapat terpengaruh. Di samping itu, penelitian yang dilakukan oleh Stephens, Young, dan Calabrese (2007) menemukan bahwa mahasiswa lebih sering menggunakan cara-cara konvensional untuk berkolaborasi saat tugas dan ujian serta menyalin tugas dan ujian daripada menggunakan teknologi. Hal tersebut memperlihatkan bahwa mahasiswa cenderung tidak menyontek menggunakan elektronik dan lebih memilih untuk menggunakan caracara konvensional dalam menyontek. Terlebih, kecurangan yang dilakukan secara elektronik seringkali dilakukan secara individual sehingga tekanan lingkungan sosial tidak sesignifikan bentuk ketidakjujuran lainnya, dan menyebabkan individu lebih dapat mengikuti perilaku-perilaku yang diterima oleh komunitas agamanya.

Adapun dimensi religiusitas yang tidak berkorelasi sama sekali dengan ketidakjujuran akademik dan dimensi-dimensi ketidakjujuran akademik adalah dimensi bonding. Hal ini bertentangan dengan penelitian sebelumnya yang mendapati bahwa individu yang sering mengikuti dan menghadiri aktivitas keagamaan lebih kecil kemungkinannya untuk melakukan ketidakjujuran akademik (Burton, Talpade, \& Haynes, 2011; Hongwei, Glanzer, Johnson, Sriram, \& Moore, 2016). Tidak adanya kaitan antara dimensi bonding dan ketidakjujuran akademik dapat dilihat dari segi agama, segi instrumen, dan segi subyek penelitian.

Dari segi agama, penelitian yang dilakukan oleh Kim-Prieto dan Diener (dalam Saroglou, 2011) menemukan bahwa umat Kristiani lebih cenderung merasakan emosi yang penuh kasih dibandingkan merasakan emosi sedih dan malu. Penelitian Shariff dan Norenzayan (2011) memperlihatkan bahwa kepercayaan akan Tuhan yang adil dan menghukum membuat individu menjadi lebih jujur dibandingkan dengan kepercayaan bahwa Tuhan adalah sosok yang pengasih. Hal ini dapat menjelaskan mengapa dimensi bonding tidak berkorelasi secara signifikan dengan ketidakjujuran akademik pada mahasiswa yang beragama Kristen. 
Penjelasan akan tidak adanya kaitan antara dimensi bonding dan ketidakjujuran akademik juga dapat dijelaskan dari segi kurikulum, di mana universitas ini lebih menekankan pada dimensi believing mahasiswa. Seperti yang tercantum dalam website universitas, pemberian mata kuliah Pendidikan Agama Kristen dan Wawasan Dunia Kristen diwajibkan bagi mahasiswa yang beragama Kristen dan Katolik, sebanyak 16 sks dari total 144 sks. Hal ini juga dapat berkontribusi pada penekanan believing dan kurangnya kultivasi aspek bonding pada mahasiswa yang membuat dimensi bonding menjadi rendah dan tidak berkorelasi secara signifikan dengan ketidakjujuran akademik.

Dari sisi data demografis usia, peneliti menemukan bahwa usia tidak berkorelasi dengan religiusitas beserta dimensi-dimensinya dan dengan ketidakjujuran akademik beserta dimensidimensinya, berbeda dengan penelitian-penelitian sebelumnya yang mendapati bahwa terdapat korelasi negatif antara umur dengan menyontek (Vandehey, Diekhoff, \& LaBeff, 2007; Olafson et al., 2013). Hasil yang didapatkan peneliti sesuai dengan hasil penelitian Teixeira dan Rocha (2008) yang mendapati bahwa tidak ada korelasi antara umur dengan menyontek pada mahasiswa di Portugal dan Spanyol yang berumur 17-26 tahun. Data demografis usia juga tidak berkorelasi dengan religiusitas. Hal ini bisa jadi dikarenakan peneliti mengambil sampel mahasiswa yang spesifik, yaitu yang berumur 18-25 tahun. Dalam tahapan umur 18-25 tahun, mahasiswa masih dalam tahapan emerging adulthood yang masih sedang meninjau ulang dan mengeksplorasi kepercayaan serta nilainilai agama yang dianut (Arnett, 2004; Arnett, 2000).

Dari sisi data demografis jenis kelamin, peneliti menemukan bahwa pria lebih banyak melakukan ketidakjujuran akademik daripada wanita. Secara spesifik, pria lebih banyak melakukan cheating dan electronic cheating. Hal ini sudah sesuai dengan penelitian sebelumnya yang menyatakan bahwa pria lebih cenderung untuk melakukan ketidakjujuran akademik dibandingkan wanita (Salleh, Alias, Hamid, \& Yusoff, 2013; Nazir, Aslam, \& Nawaz, 2011). Selain itu, penelitian yang dilakukan oleh Szabo dan Underwood (2004) menemukan bahwa pria lebih cenderung menyalahgunakan internet untuk melakukan ketidakjujuran akademik. Hal ini dapat dijelaskan melalui penelitian yang dilakukan oleh Becker dan Ulstad (2007) yang menemukan bahwa pria lebih cenderung mengambil resiko daripada wanita dan hasil tersebut terefleksikan melalui tingkat menyontek yang lebih tinggi pada pria.

Peneliti juga menemukan bahwa wanita memiliki religiusitas yang lebih tinggi daripada pria, secara spesifik wanita memiliki dimensi believing yang lebih tinggi dibandingkan pria. Hal ini sesuai dengan penelitian sebelumnya yang dilakukan oleh yang menemukan bahwa wanita lebih religius daripada pria (Hvidtjorn, Hjelmborg, Skytthe, Christensen, \& Hvidt, 2014; Bryant, 2007). Hal ini dapat dijelaskan melalui penelitian Voas, McAndrew, dan Storm (2013) yang menuliskan bahwa wanita lebih religius, karena wanita cenderung menghindari resiko. Wanita diajarkan secara sosial untuk menjadi sosok yang patuh. Oleh karena itu, jika wanita tidak religius, maka hal tersebut dianggap sebagai suatu bentuk ketidakpatuhan. Dengan menjadi religius, maka wanita dapat menurunkan resiko yang memperlihatkan wanita sebagai sosok yang tidak patuh. (Voas, McAndrew, \& Strom, 2013). 


\section{SIMPULAN DAN SARAN}

\section{Simpulan}

Melalui hasil penelitian yang telah dilakukan, dapat disimpulkan bahwa terdapat korelasi negatif yang signifikan antara religiusitas dan ketidakjujuran akademik pada mahasiswa di sebuah universitas Kristen di Tangerang. Dalam hal ini, semakin tinggi religiusitas mahasiswa, maka semakin rendah tingkat ketidakjujuran akademik mahasiswa. Sebaliknya, semakin rendah tingkat religiusitas mahasiswa, maka semakin tinggi tingkat ketidakjujuran akademik mahasiswa.

\section{Saran Teoretis}

Penelitian selanjutnya dapat menambah jumlah sampel dan menyeimbangkan total sampel antar kelompok dalam data demografis. Akan menarik juga untuk melihat dinamika ketidakjujuran akademik pada mahasiswa Kristen yang tidak berkuliah di perguruan tinggi yang berlandaskan agama Kristen. Saat menjawab kuesioner pada variabel religositas, partisipan sangat mungkin melakukan faking good. Karenanya, di penelitian selanjutnya perlu ada kewaspadaan terhadap faking good yang mungkin dilakukan partisipan.

\section{Saran Praktis}

Bagi mahasiswa Kristen, mahasiswa dapat meninjau kepercayaan, makna hidup, dan nilainilai Kristiani yang dianut oleh mahasiswa selama ini dan bagaimana hal tersebut dapat memengaruhi kehidupan akademik mahasiswa. Mahasiswa dapat melakukan peninjauan dengan diskusi bersama komunitas gerejanya, konselor, ataupun dengan dosen yang mengajar mahasiswa.

Bagi komunitas-komunitas Kristiani di universitas, peneliti menyarankan untuk mengadakan sesi forum diskusi mengenai nilai-nilai Kristiani. Dalam hal ini komunitas Kristiani dapat menjadi sarana untuk berbagi dan bertanya jawab mengenai hal-hal yang berhubungan dengan agama Kristen. Selain itu, pihak universitas atau kemahasiswaan dapat melakukan sosialisasi mengenai ketidakjujuran akademik dengan membahasnya dari aspek agama Kristiani. Dengan demikian, hal ini diharapkan dapat memperjelas dan mengingatkan mahasiswa mengenai nilai-nilai Kristiani yang diyakini, serta mengaplikasikan ajaran dan nilai agamanya ke dalam sikap moralnya sehari-hari dalam perkuliahan.

\section{REFERENSI}

Arhin, A.O., \& Jones, K.A. (2009). A multidiscipline exploration of college students' perceptions of academic dishonesty: Are nursing students different from other college students? Nurse Education Today, 29, 710-714. doi: 10.1016/j.nedt.2009.03.001

Arnett, J.J. (2016). College students as emerging adults: The developmental implications of the college context. Emerging Adulthood, 4(3), 219-222. doi: 10.1177/2167696815587422

Arnett, J.J. (2004). Emerging adulthood: The winding road from the late teens through twenties. New York, NY: Oxford University Press 
Arnett, J.J. (2000). Emerging adulthood: a theory of development from the late teens through the twenties. American Psychologist, 55(5), 469-480. doi: 10.1037//0003-066X.55.5.469

Arnold, C.E., \& Arnold, J. (2015). Short Answers to Big Questions about God, the Bible, \& Christianity. Grand Rapids, MI: Baker Books.

Bates, I.P., Davies, J.G., Murphy, C., \& Bone, A. (2005). A multi-faculty exploration of academic dishonesty. Pharmacy Education, 5(1), 69-76. doi: 10.1080/15602210500086264

BBC Indonesia. (2017, September 6). Dugaan plagiarisme di UNJ: 'Pelaku ingin naik pangkat dan dipandang tinggi'. Retrieved from http://www.bbc.com/indonesia/indonesia-41161834\#orbbanner

Becker, D. A. \& Ulstad, I. (2007). Gender Differences in Student Ethics: Are Females Really More Ethical? Plagiary: Cross-Disciplinary Studies in Plagiarism, Fabrication, and Falsification, 77-91. Retrieved from https://quod.lib.umich.edu/cgi/p/pod/dod-idx/gender-differences-instudent-ethics-are-females-really-more.pdf?c=plag;idno=5240451.0002.009; format=pdf

Bryant, A.N. (2007). Gender differences in spiritual development during the college years. Sex Roles, 56, 835-846. doi: 10.1007/s11199-007-9240-2

Burton, J.H., Talpade, S., \& Haynes, J. (2011). Religiosity and test-taking ethics among business school students. Journal of Academic and Business Ethics, 4, 1-8.

DeWall, C.N., Carter, E.C., McCullough, M.E., Fincham, F.D., Pond, R.S., Lambert, N.M., \& Nezlek, J.B. (2014). Explaining the relationship between religiousness and substance use: Self control matters. Journal of Personality and Social Psychology, 107(2), 339-351. doi: $10.1037 / \mathrm{a} 0036853$

Goforth, C. (2015). Using and interpreting Cronbach's alpha. University of Virginia Library. Retrieved from http://data.library.virginia.edu/using-and-interpreting-cronbachs-alpha/

Gravetter, F. J., \& Forzano, L .B. (2012). Research methods for the behavioral sciences (4th ed). Belmont, CA: Wadsworth Cengage Learning.

Hadjar, I. (2017). The effect of religiosity and perception on academic cheating among Muslim students in Indonesia. Journal of Education and Human Development, 6(2), 139-147. doi: 10.15640/jehd.v6n2a15

Hakim, L. (2014, Februari 17). Anggito Abimanyu mundur dari UGM setelah dituduh plagiat. AntaraNews.com. Retrieved from http://www.antaranews.com/berita/419472/anggitoabimanyu-mundur-dari-ugm-setelah-dituduh-plagiat

Harding, T.S., Carpenter, D.D., Finelli, C.J., \& Passow, H.J. (2004). Does academic dishonesty relate to unethical behavior in professional practice? An exploratory study. Science and Engineering Ethics, 10, 311-324. doi: 10.1007/s11948-004-0027-3

Hongwei, Y., Glanzer, P.L., Johnson, B.R., Sriram, R., \& Moore, B. (2016). The association between religion and self-reported academic honesty among college students. Journal of Beliefs and Values, 38(1), 63-76. doi: 10.1080/13617672.2016.1207410 
Huelsman, M.A., Piroch, J.F., \& Wasieleski, D.M. (2007). Relation of religiosity with academic dishonesty in a sample of college students. Psychological Reports, 99(3), 739-742. doi: 10.2466/PR0.99.7.739-742

Hvidtjorn, D., Hjelmborg, J., Skytthe, A, Christensen, K., \& Hvidt, N.C. (2014). Religiousness and religious coping in a secular society: The gender persective. Journal of Religion and Health, 53(5), 1329-1341. doi: 10.1007/s10943-013-9724-Z

Ismail, S., \& Omar, Z. (2017). Academic dishonesty: An empirical study of personal beliefs and values of undergraduate students in Malaysia. Pertanika Journal Social Science \& Humanities, 25(3), 1181-1198.

Kirkpatrick, L.A. (2005). Attachment, Evolution, and the Psychology of Religion. New York, NY: The Guilford Press. doi: 10.1163/008467206777832616

Koole, S.L., McCullough, M.E., Kuhl, J., \& Roelofsma, P.H.M.P. (2010). Why religion's burdens are light: From religiosity to implicit self-regulation. Personality and Social Psychology Review, 14(1), 95-107. doi: 10.1177/1088868309351109

Lawson, R.A. (2004). Is classroom cheating related to business students' propensity to cheat in the "real world"?. Journal of Business Ethics, 49, 189-199. doi: 10.1023/B:BUSI.0000015784.34148.cb

Mukti, A.H. (2017, Agustus 7). Tarifnya ratusan juta, 2 joki ditangkap polresta Solo. Tribun Jateng. Retrieved from http://jateng.tribunnews.com/2017/08/07/tarifnya-ratusan-juta-2-jokiditangkap-polresta-solo

Nazir, M.S., Aslam, M.S, \& Nawaz, M.M. (2011). Can demography predict academic dishonest behaviors of students? A case of Pakistan. International Education Studies, 4(2), 208-217. doi: 10.5539/ies.v4n2p208

Nelson, M.F., James, M.S.L., Miles, A., Morrell, D.L., \& Sledge, S. (2016). Academic integrity of millennials: The impact of religion and spirituality. Ethics and Behavior, 27(5), 1-16. doi: 10.1080/10508422.2016.1158653

Neyrinck, B., Vansteenkiste, M., Lens, W., Durienz, B., \& Hutsebaut, D. (2006). Cognitive, affective, and behavioral correlates of internalization of regulations for religious activities. Motivation Emotion, 30, 323-334. doi: 10.1007/s11031-006-9048-3

Olafson, L., Schraw, G., Nadelson, L., Nadelson, S., \& Kehwald, N. (2013). Exploring the judgementaction gap: College students and academic dishonesty. Ethics and Behavior, 23(2), 148-162. doi: $10.1080 / 10508422.2012 .714247$

O’Rourke, J., Barnes, J., Deaton, A., Fulks, K., Ryan, K., \& Rettinger, D.A. (2010). Imitation is the sincerest form of cheating: The influence of direct knowledge and attitudes on academic dishonesty. Ethics \& Behavior, 20(1), 47-64. doi: 10.1080/10508420903482616

Piedmont, R. L. (2014). Inter-item Correlations. In A. C. Michalos (Ed.), Encyclopedia of Quality of Life and Well-Being Research (3303-3304). Dordrecht: Springer Netherlands. doi: 10.1007/978-94-007-0753-5_1493 
Prasad, E. (2013). What does it mean to glorify God?. Retrieved from http://nlbpc.org/web/posts/852

Pyysiainen, I. (2017). The evolution of morality and relgiion. In P. Luomanen, A.B. Pessi \& I. Pyysiainen (Eds.), Christianity and the Roots of Morality Philosophical, Early Christian, and Empirical Perspectives (Vols.8) (pp. 44-64). Danver, M.S: Koninklijke Brill nv. doi: 10.1163/9789004343535_009

Rujoiu, O. \& Rujoiu, V. (2014). Academic dishonesty and workplace dishonesty. An overview. Proceedings of the 8th International Management Conference, "Management Challenges for Sustainable Development", November 6th-7th, 2014, Bucharest, Romania.

Saana, S.B.B.M., Ablordeppey, E., Mensah, N.J., \& Karikari, T.K. (2016). Academic dishonesty in higher education: Student's perception and involvement in an African institution. $B M C$ Research Notes, 9(234). doi: 10.1186/s13104-016-2044-0

Salleh, M.I.M., Alias, N.R., Hamid, H.A., \& Yusoff, Z. (2013). Academic dishonesty among undergraduates in the higher education. International Journal of Academic Research, 5(2), 222-227. doi: 10.7813/2075-4124.2013/5-2/B.34

Saroglou, V. (2011). Believing, bonding, behaving, and belonging: The big four religious dimensions and cultural variations. Journal of Cross-Cultural Psychology, 42(8), 1320-1340. doi: $10.1177 / 0022022111412267$

Saroglou, V. (2014). Religion, Personality, Social Behavior. V. Saroglou (Ed.). New York, NY: Psychology Press. doi: 10.4324/9780203125359

Shariff, A.F., \& Norenzayan. (2011). A. Mean gods make good people: Different views of God predict cheating behavior. The International Journal for the Psychology of Religion, 21, 8596. doi: 10.1080/10508619.2011.556990

Stephens, J.M., Young, M.F., \& Calabrese, T. (2007). Does morale judgement come offline when students are online? A comparative analysis of undergraduates' beliefs and behaviors related to conventional and digital cheating. Ethics \& Behavior, 17(3), 233-254. doi: $10.1080 / 10508420701519197$

Stogner, J.M., Miller, B.L., \& Marcum, C.D. (2012). Learning to e-cheat: A criminology test of internet facilitated academic cheating. Journal of Criminal Justice Education, 24(2), 1-25. doi: 10.1080/10511253.2012.693516

Sugiyono. (2014). Metode penelitian kombinasi (mixed methods). Bandung, Jawa Barat: Alfabeta.

Szabo, A., \& Underwood, J. (2004). Cybercheats is information and communication technology fueling academic dishonesty?. Active Learning in Higher Education, 5(2), 180-199. doi: $10.1177 / 1469787404043815$

Teixeira, A.A.C., \& Rocha, M.F. (2008). Academic cheating in Spain and Portugal: An empirical explanation. International Journal of Iberian Studies, 21(1), 3-22. doi: 10.1386/ijis.21.1.3/1

Tong, S. (2012). Allah Tritunggal. Surabaya, Jawa Timur: Penerbit Momentum. 
Vandehey, M.A., Diekhoff, G.M., \& LaBeff, E.E. (2007). College cheating: A twenty-year follow up and the addition of an honor code. Journal of College Student Development, 48(4), 468-480. doi: $10.1353 /$ csd.2007.0043

Voas, D., McAndrew, S., \& Storm, I. (2013). The nature and future of the gender gap in religiosity: Evidence from cross-national European surveys. Kölner Zeitschrift für Soziologie, 65(1), 259283.

Wright, N.T. (2006). Simply Christian Why Christianity Makes Sense. New york, NY: Harper Collins Publishers

Zacharias, R., \& Geisler, N. (2003). Who Made God? And Answers to Over 100 Other Tough Questions of Faith. Grand Rapids, MI: Zondervan 